\title{
THE EVOLUTION OF ROMAN FRONTIER CONCEPT AND POLICY
}

\begin{abstract}
The Roman power is, ideologically, infinite in time and space. Nevertheless, the Roman state had experienced a wide variety of territorial limits, evolving in time and space, more or less throughout a millennium. If at first the Roman state, limited to Rome metropolitan area, later to the Italian peninsula, was easily defensible, beginning with the heavy expansion, also came trouble. The Romans, always innovating, find solutions for the fortification of the contact zones with the Barbarians. The Roman frontier concept was fundamentally different from the modern one. If the defence of Roman possessions was obviously priority, the border should remain an open ensemble, allowing for the free circulation of people and goods, some of the fundamental Roman rights. The peak of Roman expansion, $2^{\text {nd }}$ century A.D. brings also the maximum development of the Empire frontier. Dacia overlaps widely chronologically on this trend, this being one of the reasons for one of the most complex frontier system in the Empire.
\end{abstract}

Keywords: Rome, frontier, limes, army, strategy.

$\mathbf{T}$ he Roman frontier area is first and foremost a market, where demand is always present, varying a lot in intensity. Provisions practically dictate evolution and Romanization. The Roman frontier is a complex phenomenon, comprising different regions, with different characteristics, impossible to generalize. The Romans have a long tradition of negotiating with other people. The limited number of citizens during the time of the Republic prevents massive colonization and the presence of garrisons is not popular. That is why Romans opted for understanding with those whom they conquered, even more so because they usually occupy densely populated and economically developed areas. In order for this process to be successful the Roman are counting on the local elites, which they convert to a Roman life style. A pacified society is what is needed behind the scenes in order to fulfil the needs of the army ${ }^{1}$.

The Roman frontier of the Republic involves several forms of organization. Roman wars in the west did not have a selfish and triumphant connotation, except for a few particular cases. These tendencies were visible especially in the East. Most of the changes on the western frontiers were the result of changes developed over many generations or the logical extension of a temporary status. This haphazard way of extending an empire is obvious in the long history of Gallo-Roman wars that led the latter from the Pad valley until the Alps and, in the end, the Ocean. In the northwestern Mediterranean Sea, the intersecting relations with Massalia and Saguntum led to control

\section{George Cupcea}

Western University, Timișoara george.cupcea@gmail.com

\footnotetext{
${ }^{1}$ DRUMMOND/NELSON 1994, 9, 12, 18-9.
} 
being extended over this area ${ }^{2}$.

During the time of the Republic it is impossible to find something remotely similar to the frontiers of the Empire. Still, one of the first references to a limit belongs to Cato the Elder: the Alps are like a wall protecting Italy, at a time when the Romans had not yet conquered Cisalpina. T. Livius recounts how in 183 B.C. a tribe of transalpine Gauls was forbidden to settle in Cisalpina, the Alps being considered an impassable frontier (39.54.10-12: prope inexsuperabilem finem). There was no proto-limes system in the Republic, except for the civilian limits of the settlements, defined in the forma provinciae, such as the fossa regia from Numidia. Theoretical limits of Roman power were put forward by Caesar - the Rhine ${ }^{3}$ or Pompey - not recognizing the Euphrates as a frontier with the Parthians ${ }^{4}$.

Nowhere in the west did the Roman frontiers ever pass over an ecologic barrier. The Romans practically encountered sedentary, agrarian societies and the only aggression manifested by the former was the raid and not the migration (the Cimbri and the Teutons are the only exception). The climate was the same, in the islands and Hispania or southern Gaul, only Caesar taking the decisive step towards Europe ${ }^{5}$.

This attitude is connected with the unclear notions of provincia and imperium, notions that did not superimpose over an established territory. Anyway the externae gentes were under Roman power but they were included among the fines only in times of dire need - bellum iustum. The first Roman maps are those of Sardinia and then the one ordered by Caesar. In theory the Romans considered themselves at the centre of the Earth, situated in a perfect area, from all points of view, to grant them mastery over the whole world ${ }^{6}$.

During the development of the Republic the magistrates had juridical duties in Rome and were military commandants on the field. The area of competence of a magistrate who is in the field is called provincia. The first province is Sicily, starting from 271 B.C. Initially controlled by an allied king it is brought under complete Roman control after the first Punic war. At this period in time the Romans abstained from exercising direct control, they preferred to do so through vassal kings, but as the state expanded unavoidably, the need for more magistrates led to prorogation, in turn leading to the creation of huge Roman power centres located outside Rome. In this system, a king was entitled as socius et amicus populi Romani, his kingdom being in fact considered a part of the Roman state ${ }^{7}$.

During the time of the Republic there was also no pressure from the population towards expansion. Practically the Romans did not eliminate the people they encountered, associating them instead. With a few exceptions in the ager Gallicus, where people where brought over and colonies established due to circumstantial reasons, the Roman frontier was an exhaust valve for the poor (like the western one of the USA); those who left definitively were the

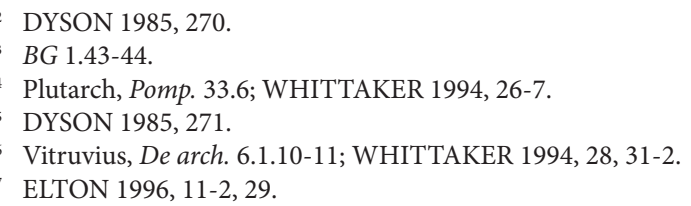

entrepreneurs ${ }^{8}$.

Most of the settled colonists were veterans who knew the area and the natives, engaged in business with them, entered mixed marriages and probably were rapidly integrated in that developing Roman community. Some of them even renounced their Roman life, moving over in the oppida beyond the border. In the west the Romans met no racial barrier they could not overcome, their organic conflict with the Gauls from Cisalpina being an exception. Once the barbarian leaders were cowed into submission they themselves became agents of Romanization ${ }^{9}$.

Mineral resources and trade made the western Roman frontier more complicated. Once a mining area was conquered the need for control and cheap labour force meant social tensions that could erupt into rebellion. This is true for Hispania, but not for Noricum; in the latter case the exploitation of resources was done after reaching consensus with the natives and this led in turn to mutual profit. Romans inherited the trade routes from those whom they conquered (Greeks, Gauls and Carthaginians). They encouraged trade and market as phenomena of acculturation but as trade routes extended north and commerce with luxury items appeared, the situation got complicated. We are seeing the appearance of very rich families or tribes that try to take control over the trade routes ${ }^{10}$.

On the other hand a centralized establishment includes border stability. Armed forces on the border were practically non-existent, just like for a real borderline. The governor relied mostly on urban militias and a small, semiprofessional administrative body, thus he was forced to establish strong relationships with the local leaders even for security matters. There did not exist a clear political demarcation because most of the groups from the area enjoyed all types of relations on both sides of the border. They were encouraged and administered from the point of view of diplomacy by the Romans. Aggression on the frontier was probably something common in that time period but the governor had to act only to confine such phenomena to a local level. Besides, this frontier policy was largely decided in Rome, in the Senate, whose members were aristocrats with different interests in the frontier areas ${ }^{11}$.

Caesar, the sacker of the Republic, made the most significant changes in border policies. Despite abuses on both sides, it was only in a peaceful and relatively content that evolution could reach the provincial developed world of the Empire ${ }^{12}$.

The Romans were bound by ideology to expand, to rule all peoples, according to what Jupiter promised to Venus: imperium sine fine dedi. ${ }^{13}$ Thus, the Romans always assumed their power would extend indefinitely. Augustus, in his preamble to Res Gestae, claims to have bound all the nations of the world to the Romans, in that he had the highest success and that the process was ongoing ${ }^{14}$. From their

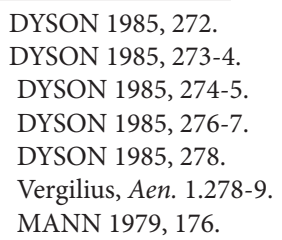


point of view the Romans already owned at the beginning of the Principate the whole orbis terrarium. This philosophic idea excludes the notion of frontier but also separates the barbarians from the civilized world. The experience was however different, proving that relations and contacts with this barbarian world were permanent ${ }^{15}$.

The advice given to Tiberius ${ }^{16}$ is wrongly interpreted to justify the halt of the expansion ${ }^{17}$. Augustus' will does not prevent the Empire from expanding in the future but it underlines however the importance of keeping peace where she already existed; he himself does not look for unprovoked aggression - all his wars were just - Suetonius, Aug. 21.2 $2^{18}$.

It is due to Augustus and the firing of more than half of the Roman army that Rome enters a static period, one of pacifying and stabilizing the conquered territories. After the failures from Illyricum and the Teutoburgic Forest, Augustus leaves a testament seemingly stating that the Empire should not expand anymore. Thus, the legions are placed in strategic points, on the Rhine and then the Danube and start altering the landscape around them ${ }^{19}$. The first sign of frontier policy is this advice given by Augustus to his followers. However he does for forbid expansion but suggests moderation, with a focus on the more profound Romanization of the already conquered provinces, which turned out to be mandatory after the rebellion from Illyricum and the Varian disaster ${ }^{20}$. Augustus did not extend the borders needlessly but in order to reach natural obstacles difficult to overcome - Rhine, Danube, in order to establish communication paths from all sides towards Italy and to block the access of other people in the controlled areas. He set up the line between the areas of internal and external control ${ }^{21}$.

During the pacifying process Augustus had to deal with several challenges. Firstly he reduced the number of legions to less than half, thus creating a large number of colonist-veterans that played a decisive role in Romanization. Secondly he established a permanent professional military service paid for by the state. Although he closed the gates to the temple of Janus (29 B.C., opened since 235 B.C.), meaning that Rome was at peace with the rest of the world, this peace lasted but very little. The rebellions of the Germans allowed for the extension of the Empire towards the Danube, those from Illyricum kept the Romans on their edge for almost 20 years and the Varian disaster stopped the expansion in temperate Europe. Practically it was concluded that it was not economic sustainable, that an army so far away from the civilized world was hard to support and supply; this meant that, somewhat unconsciously, the troops returned on the Rhine-Danube river supply line and started establishing there ${ }^{22}$.

With regards to the conquest of Germany, Augustus seems to have prepared the field and the internal security of the Empire for this until 13 B.C.: Numidia, Southern Egypt, Parthia, north-western Hispania, the Alps, and the Danube

\footnotetext{
15 BREEZE/JILEK 2005, 142.

16 Tacitus, Ann. 1.11 - coercendi intra terminos imperii.

17 MANN 1979, 177.

18 WHITTAKER 1994, 29-30.

9 DRUMMOND/NELSON 1994, 6-8.

WHITTAKER 1994, 33-5.

21 WHITTAKER 1994, 38, 43.

22 DRUMMOND/NESLON 1994, 20-21.
}

areas seem to have been pacified with this purpose in mind. After all of this he must have been discouraged by Varus' disaster. His descendants were content with preserving what they inherited ${ }^{23}$.

The most surprising thing about the Julio-Claudine security system is the economy of force. Control over a vast territory was ensured by a rather small army. The total of the armed forces, both legions and auxilia, was around 300,000350,000 soldiers. The reduction in the number of legions after the battle of Actium, from 60 to 28, was dictated not necessarily by financial needs but rather by a rational plan of distributing the military forces. Tacitus seems to best explain the situation: Ann. 4.5 - in the year 23 A.D. there were eight legions on the Rhine, three in Hispania, two in Africa, two in Egypt, four in Syria, two each in Moesia and Pannonia (a total of four on the Danube), finally two in Dalmatia for a total of 25. Although it seemed that this distribution did not allow for a strategic reserve, located behind the lines, this is created by the troops from Rome and the two Dalmatian legions. In fact this scheme does not reflect any need for external defence but instead that of internal security. The three Hispanic legions are there to finalize an ample pacification process over a huge area that is difficult to reach. The two legions from Dalmatia assist those from the Danube in order to prevent a large rebellion such as the one from 6-9 A.D. The same is true for Egypt ${ }^{24}$.

There is still no visible frontier, nor were the troops brought together in permanent stone fortifications, but rather in tents and wooden fortifications, constructed after the design of marching encampments. They are placed near the important roads; the legions are now part of a mobile field army, easy to despatch. In fact most of the problems of this time are internal rebellions: Pannonia, Tacfarinas, Florus and Sacrovir, the Jewish wars. Colonies are another instrument for spreading Roman authority in a hegemonic empire. Introduced by Caesar, the system involves placing communities comprised of veterans and soldiers in areas where there are no troops stationed, in order to establish primary security. A perimeter defence is missing and thus so is a linear border. The meaning of the word limes is that of an access road positioned perpendicularly on the defensive line $^{25}$.

The example of Palestine where, after the fall of the kingdom of Herod, smaller or greater permanent military concentrations were needed, is relevant. This system of concentrating troops in a single area (until forbidden by Domitian ${ }^{26}$ ) had the role of ensuring mobility of a large number of forces in critical area, because there are no great threats. A disadvantage of this system is that troops travelling from a critical point to another area of interest leave behind a vacuum of power that can give birth to massive rebellions - Illyricum 6-9 A.D. The evolutions in the expansionist policy Rome conducted in the $1^{\text {st }}$ century B.C. led to the creation of this Augustus-inspired system of expansion. In fact the whole system was based on this idea and the Roman concept of geography put together with that of the universal empire

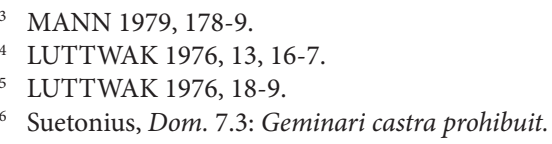


did nothing to hamper their ambitions ${ }^{27}$.

The security system of this period was mostly ensured by client states: Mauretania, the Jewish tetrarchies, the other small Syrian states, the Lycian League, Commagene, Pontus, Cappadocia, the Bosporan Kingdom, Thracia, Alpes. Problems are connected with the barbarians living across the Rhine and Danube, who do not share the same state and diplomatic traditions of the Greek-Oriental world. In fact, after the Varian disaster, the Romans, although retreated from the area, still intervene in the diplomacy of the Germanic people establishing a chain of client tribes from the Rhine until Theiss and the Danube. Such client tribes were not official subjects - amicus populi romani - but they fell into the Roman category of patronus - clientus type of relations. Client states generally were not buffer states. In fact they must be active and ensure border security. Also all of these states must protect their internal security as well, so their defensive system is intertwined with the Roman one ${ }^{28}$.

Augustus is in fact deeply involved in their internal, even personal problems. Strabo claims 'these kings and dynasts are and always were in the imperial part of the state'. ${ }^{29}$ It is also Strabo the one who says that the Euphrates is the eastern frontier, ${ }^{30}$ no matter the presence of client states and Tacitus includes the forces of the client kings in the Empire's armies. ${ }^{31}$ It has not been clearly established whether these kings paid tribute or received subsidies but it is clear mutually financial transactions existed between them and the Roman state. The most significant contribution of client kings was recruiting armed forces. Such forces could be included in the Roman army if the kingdom was annexed or inherited - the 30 cohorts of king Deiotarus of Galatia become legio XXII Deiotariana. The Romans immersed themselves frequently in the kingdoms, in favour of kings they backed ${ }^{32}$.

In the period of the Principate, mostly the first two centuries A.D., Roman expansion seems to come to a halt. As mentioned before this is just an impression. In truth, the emperors who do not expand the Roman state are intensely criticized, ${ }^{33}$ and those who achieve the most in this area are praised and called propagatores imperii (Marcus Aurelius, Lucius Verus, Septimius Severus, Constantine I). With regards to the expansion in Iran it is very likely that the Romans could have controlled the area because of the large urban development and resources much in the same way Alexander and his descendants controlled it, the latter being inferior to the Romans in terms of organization and politics. Free Germany was a densely populated area with great agricultural potential. What made the Romans show prudence here and not in other cases: Britannia, Dacia? Perhaps these minimal efforts at expansion are due to the need of those emperors to gain military glory ${ }^{34}$.

27 LUTTWAK 1976, 25, 47-9, 50.

28 LUTTWAK 1976, 20-1, 24

29 Strabo, 17.3.25.

30 Strabo, 16.1.28

31 Tacitus, Ann. 1.11, 4.5, 15.45; Hist. 4.39

32 LUTTWAK 1976, 25; ELTON 1996, 29, 30-1.

33 Tiberius by Tacitus, Ann. 4.32.

34 MANN 1979, 177-8. The main military evolution from Augustus to Hadrian: the invasion of Britannia, the conquest of agri decumates, the establishment of systematic frontiers on Rhine and Danube, Domitian's and Trajan's Dacian wars, Hadrian's retreats and systematization of circulation,
The movement of military forces on the frontier lines starts with Emperor Claudius and not necessarily the $2^{\text {nd }}$ century. The stabilization of frontiers in the $2^{\text {nd }}$ century is subjected to the immense variation of the Roman defensive system. The least fortified frontiers are those from Africa Tripolitania where we encounter no defensive garrisons until the time of Commodus-Septimius Severus. It is possible that before this period the fortified farms served for indepth defensive purposes, because the only enemies in the area were either friends or were watched - Garamantes ${ }^{35}$. The decision of placing frontiers was not a conscious one, because the goal and ideal of each and every military commander, governor or emperor was expansion and military glory. For example: the punishment of the Germans by Tiberius, agri decumates, Britannia and the changes in its northern frontiers (especially Severus' campaigns conducted for the purpose of educating his sons and prevent the legions from becoming bored), the Marcomannic Wars and the intention to create two new provinces ${ }^{36}$.

Concerning the Eastern frontier this was never accepted as a final one (Nero, Trajan, Marcus Aurelius, Septimius Severus - tried to conquer the Persians). The Romans could not always foresee the course and result of a conflict. Still, the main reason for aggression remains the desire for glory and/or the majesty of the Roman people. ${ }^{37}$ Nowhere is it stated that the Roman state was responsible for the security of its inhabitants (only of its citizens), thus it is likely that this was not an official priority (perhaps only the security or resources and of the economy). Septimius Severus argument for the war with the Parthians is that it is meant to secure the area around Antioch but it is just as unrealistic as the one presented by Agricola when conquering Ireland (a station positioned halfway between Britannia and Hispania!). Thus Roman imperialism does not have a territorial focus but rather an ethnic one: Rome conquers peoples, not territories, has client kings, not kingdoms etc. We have no territorial references for the expansion of the Empire, only ethnical ones and the only geographical coordinates are the provinces ${ }^{38}$.

The system comprising client states disappears because the Empire can defend itself, it is better established around control areas and because we are witnessing Vespasian's centralizing process. In the Danube area the Dacians are conquered because they no longer fit the pattern of a $1^{\text {st }}$ century client state while the Sarmatians, much like the Armenians, became buffer areas rather than client states $^{39}$.

A key element in the Roman frontier defence strategy is the marching camp and the establishment of a clear line of demarcation. This structure had a defensive efficiency thanks to several factors: it provided a protected camp, it systemized night life and it offered the minimal

the purpose of regulating the frontiers and circulation was development of commerce. DRUMMOND/NELSON 1994, 24-31.

35 MANN 1979, 179.

36 ISAAC 1992, 388-90.

Plinius, Pan. 12.2, 178.4.

ISAAC 1992, 391-5.

9 LUTTWAK 1976, 110, 117. 
comfort needed for soldiers to be ready at a moment's notice. In fact it is the Flavian and later on the Antonine dynasties that instituted the marching camp as a very important element in the defence of the Empire ${ }^{40}$.

Frontiers begin to change as client states are annexed and a clear line of demarcation is established. Hadrian goes so far as to mark down in the field the frontiers of the Empire through artificial defence lines. The system of artificial barriers was not insurmountable, but adapted to the type of threat faced. Actually it meant organizing an infrastructure in order to supervise and organize military forces in an area with the purpose of mounting an offensive outside of the province ${ }^{41}$.

Watchtowers fulfil this role and they also serve to signal any danger. Fortifications placed between $50-80 \mathrm{~km}$ ahead of the frontiers meant in-depth surveillance of the territory (north of Hadrian's Wall, south of fossatum Africae). The towers had optimal visibility towards the territory of the province so that they could use smoke/fire signals as efficiently as possible to warn the camps and the troops. The signals followed surveillance lines towards the inside of the province, towards the fortifications of ala or legions (the line Hadrian's Wall - York; the line Poieni-Gilău-Turda). Everything was based on an efficient system of roads connecting in-between the fortified camps and the towers, limes roads that ensure information travelled quickly and the efficiency of the system of signalization ${ }^{42}$.

The artificial barriers were not designed as battle platforms but rather as observation points, for sending out signals and maybe on-the-spot defence against raids. For example, any ditch followed by a palisade is an insurmountable obstacle for cavalry because it interrupts the attack and thus makes it useless. Once in the province, a barrier helps to keep the enemy in the Roman controlled area, the only point of exit being the point of entrance. Still, such lines are efficient only against small invasions - the raids. A systematic invasion, on a large scale, needs another defensive system, an in-depth one, like in the East ${ }^{43}$.

The mobility of the Roman army was provided by its nearly 80,000 cavalrymen who served in the alae and mixed cohorts, alongside the legionary cavalry. Anyway, the only area where the enemy could field a large army comprised of cavalry was Parthia. In truth, the Roman military forces were not set up in a linear, constant pattern. We can see, for example, that on Hadrian's Wall out of about 30,000 troops (the legions and the auxilia behind them), only a maximum of 3,000 were encamped in small forts and watchtowers ${ }^{44}$.

Hadrian alters the Flavian border tactic by moving auxiliary troops along the defensive line and thus making it less mobile. In fact he only brings auxiliary troops closer to the areas where intervention might be required. In the $2^{\text {nd }}$ century this system is organized on several layers: 1 . Raids are intercepted right on the borderline by the troops residing in the burgi. 2. Well-organized invasions are intercepted by the auxiliary troops stationed on the limes or right behind it. 3. Large-scale invasions are halted by the legions. In all cases

40 LUTTWAK 1976, 55-7.

${ }^{41}$ LUTTWAK 1976, 60-1

42 LUTTWAK 1976, 66-7.

43 LUTTWAK 1976, 68-9.

${ }^{44}$ LUTTWAK 1976, 71-3. the borderline also ensures a rear-guard. Thus, troops are organized based on their level of mobility, from the border to the interior of the province ${ }^{45}$.

The situation of the desert provinces of North Africa and the East is different. There, the Romans are not interested in most of the land. Civilization is concentrated around oases, villages, cities, depending upon the sources of water and an efficient system of roads. Here punctual defence is preferred, defence of the cities and of areas of interest, and a demarcation line is no longer needed ${ }^{46}$. Fossatum Africae had the role of protecting the social and economic security of a wide area of interest to the Romans ${ }^{47}$. The garrison on the frontiers of Cyrene and Africa was very small, probably just as the danger of that area. It is only in Numidia that we find a border similar to the one from Europe, destined to control transhumance ${ }^{48}$.

On the Rhine-Danube frontier, mostly the provincial fleets did the patrolling, the border area being marked only by watchtowers and a road ${ }^{49}$.

Mauretania Tingitana and Dacia are similar from this point of view: they do not have clear fortification lines, with troops stationed there, but rather a general disposition of troops, probably along the communication lines. The obvious differences between the two artificial barriers, Hadrian's Wall and the Upper German-Raetian Limes, proves that the Romans preferred to react and adapt to each separate situation rather than apply a general valid model ${ }^{50}$.

In fact this is the most important role of the limes, to provide security to a developing area that has to generate economic growth, surplus, develop, urbanize and Romanize. The system of regionalizing armed forces is the most logical that could be applied to the Roman Empire, with its borders spread across thousands of kilometres, without the technical possibility of covering large distances quickly and thus of centralized defence. According to the principle that the borders must not enclose the largest territory possible but the territory best suited to control, experiments such as the Antonine Wall, the German limes on the Elbe or other advanced limites failed ${ }^{51}$.

By adapting, the Roman unknowingly created the notion of border. The first and foremost priority was the security of the Empire and to this end Rome possessed huge military forces. Firstly it was used at a visual level, to intimidate, just like the military installations on the borders. We can observe major changes on the borders during the reigns of Trajan (caused by the Dacian wars), Hadrian and Septimius Severus. The problem is who takes the decision and up to what point ? $^{52}$ There are no clearly drawn provincial lines, thus we can assume the individuality of each one and thus of the way of governing. For example, when the provinces of Upper Germany and Raetia were expanded, the border on the two sectors was made of different building

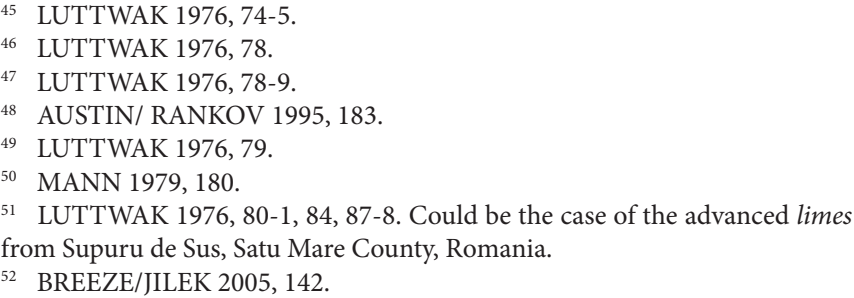


materials. The problem of decisions taken in the field is very simple: they had to be taken by experienced persons, with advanced topographic knowledge of the area and of military structures - thus superior officers ${ }^{53}$.

The term limes has meanings beyond the simple one of military border: $1^{\text {st }}$ century - military road in Germania, $2^{\text {nd }}-3^{\text {rd }}$ centuries - Empire border, $4^{\text {th }}$ century - frontier district under the command of a dux; finally there is no Latin term for military border. Thus the military installations placed on the border must have had different purposes at different moments in time, purposes that cannot always be understood. In general, the areas where fortified camps were placed were temporary and adaptable ${ }^{54}$.

There were no markings for the borders of the Empire, only for administrative limits, for those of provinces, cities, civitates etc., simply because they involved administrativefinancial divisions, some dating back to before the Roman period. The only map we have to the date, Tabula Peutingeriana, makes no reference, nor does it mark frontiers. The case of frontiers of the provinces Arabia or Egypt, which, although established at some time, leaves garrisons outside it, is but an example of differentiating between administrative, ethnic and military frontiers. In any case there existed contact and interaction just about everywhere across the border: across the Rhine - Lower Germany, across the Danube - Slovakia, across the Euphrates - Nisibis ${ }^{55}$.

The apparent irregular shape of the frontier shows that for the Romans it did not matter much its course. Geographical knowledge was primitive and the surviving maps are completely unusable by the military. Also, intelligence was lacking, especially in the East ${ }^{56}$. Despite the frumentarii, some believe that Rome did not have an official intelligence system, or troops that would exercise political control over the army ${ }^{57}$.

Indeed, the information the Emperor received in Rome about the frontiers was superficial and did not allow for conscious decisions. Most of the decision-making had to be done by the governor on the spot, with the Emperor intervening only for political reasons. Although not mentioned in literature there must have existed correspondence between the governor's office and the frontier fortifications. The governor sent orders, dispositions and

\footnotetext{
53 BREEZE/ JILEK 2005, 143.

54 ISAAC 1992, 408-9.

ISAAC 1992, 396-9. Frontier regions generally have a small area: Britannia - between the fortified camps and Hadrian's wall, very good economic development to supply the troops; the lower Rhine - very little development and scarcely populated, still it had access to important ways of communication; Rhine-Danube - economically prosperous area, trade with the Germanic people; Danube - initially poorly developed, develops as troops are moved here; Dacia and lower Danube - the most successful roman border experience, it develops due to available resources, lands and trade with northeast Europe. DRUMMOND/NELSON 1994, 31-2.

56 ISAAC 1992, 401-5. The failure of Ael. Gallus in southern Arabia, as well as those of Crassus and M. Antonius in Parthia are blamed on the treacherous guides disorienting them. This proves once again that the Roman army did not know the geography of the area where it campaigned. The same is true for Germany; only after the Varian disaster to they realize the size of the territories and of the populations from the area. Other examples of Romans displaying poor geographical knowledge during campaigns: Septimius Severus in Mesopotamia and Britannia, Nero in Armenia etc.

57 ISAAC 1992, 406-7. contra AUSTIN/RANKOV 1995.
}

instructions (Fink 98). ${ }^{58}$ Such curriers are found everywhere: Dura, Vindolanda, Egypt. Correspondence was also carried with the spies/scouts from across the border. ${ }^{59}$ Information reaching the governor was differently interpreted than right on the border since the perspective was centralized and tactically focused over the whole frontier sector. One of the results of creating static frontiers and provincial centralized bureaucracy was the creation of a cyclical information system, more efficient and more regular than was possible at the time of the Republic ${ }^{60}$.

The most important uniting factor of the European frontier of the Roman Empire is at the same time a natural barrier - water. Almost continuous navigation ways, from the North Sea to the Black Sea, along the Danube, Main and Rhine ensured the economic growth necessary to the area and also quick access to critical areas ${ }^{61}$. Rivers, just like roads, were considered as means for transport/communication, not as barriers. Examples of the ease with which these barriers were passed: Caesar crosses the Rhine on a bridge, ${ }^{62}$ the Germans with boats and rafts ${ }^{63}$ and the Batavians swim equipped with weapons. ${ }^{64}$ In fact the Romans probably considered rivers more like obstacles against preventive attacks. It is because of this that bridges and bridgeheads are established over rivers, especially by Constantine ${ }^{65}$.

Most of the scholars of the Roman frontiers, from the theoretical point of view, consider that rivers are not frontiers but rather communication lines (Luttwak, Mann, Maxfield, Isaac, Whittaker $)^{66}$. Their arguments are analogies with modern military strategy, while many ancient sources tell us the Romans considered rivers are defensible frontiers. ${ }^{67}$

The honorary inscription set up for Ti. Plautius Sivanus Aelianus, from Tivoli ${ }^{68}$ indicates that Danube was considered a frontier, defended and defensible. Seneca ${ }^{69}$ shows that the Rhine and Danube separate the civilized areas and the hostile ones and the depth and mobility of rivers are in themselves defensible elements. There are accounts about rivers being used as defences also by the barbarians - Tacitus, Agr. 15.3, Plinius, Pan. 16.5. If rivers are considered offensive zones by the Romans then why do they all fortifications in the $2^{\text {nd }}$ century on their side of the river instead of on the other shore? The logistic advantage would not be lost. During the Principate, the Romans did not maintain bridges across the main rivers. The bridge from Cologne was destroyed after Germanicus' return in order to stop Germanic invasions. ${ }^{70}$ Trajan builds bridges across the Danube and Euphrates because he envisages easy access in the newly conquered provinces, ${ }^{71}$ but Hadrian destroys the 58 FINK 1971, no. 98.

59 T.Vin. II 164 - about Britons and battle preparations.

60 AUSTIN/ RANKOV 1995, 170-2.

61 DRUMMOND/NELSON 1994, 32

62 BG 4.16.1, 4.17.

63 $B G$ 6.35.7

64 Tacitus, Ann. 2.8, Hist. 2.17, Dio, 66.9.6.

65 ISAAC 1992, 410-2.

66 The complete discussion in AUSTIN/RANKOV 1996, 173-80.

7 Josephus, BJ 2.16.4; Statius, Silv. 5.1.89-90; Tacitus, Ann. 1.9, 4.5; RANKOV 2005, 175-6.

68 CIL XIV 3608

69 Seneca, QN 6.7.1.

70 Tacitus, Ann. 1.69

1 Amm. Marc. 24.3.9. 
one from Drobeta in order to prevent access in Moesia ${ }^{72}$.

It is obvious that the Romans did not consider river frontiers as impassable - drought ${ }^{73}$ or frost ${ }^{74}$ can seriously hamper defences. The invasions carried across the Danube by the Dacians, Iazyges and Germans, are few, spread across a period of 450 years, thus the river frontier is generally efficient. Rivers are generally dangerous when crossed over. Fords are not numerous or are well defended by the Romans. Swimming is very dangerous for the infantry. ${ }^{75}$ The Batavian cavalry was trained for this and proved it by crossing over in several occasions: Thames, Britannia, Danube - under Hadrian's gaze - etc. but we have no reason to believe all cavalry had this skill. Mobile bridges are the favourite method of the Roman army for crossing over but this requires special resources and techniques. Still, crafts were the method most used; this is mostly done by the Romans. Barbarians had at their disposal few small boats, suited for raiding. In this situation they are somewhat vulnerable and the burgi placed along rivers in the $2^{\text {nd }}$ century serve to prevent just such incursions ${ }^{76}$.

As far as fortifications along the Danube are considered it seems that they were not placed to control rivers crossings but the river itself. In the case of the legionary fortress of Novae it seems it is placed just exactly where an unstable portion of the river - impossible to supervise - starts, at the joining between Danube and one of its tributaries; a port, protected from the main current, could have been placed there. It is interesting that this problematic river sector ends at Sexaginta Prista, a presumable naval base, with a similar topographical position. Generally, fortifications along the Danube were placed in points where topography changes, the beginning or end of plains subjected to flooding or difficult mountain areas. From such areas it is easy to control traffic and even cross the river. Locations where the river undulated, where the joining of rivers allowed for ports to be built, were preferred; such placed did not depend on routes previously established by the Romans. On the Main river fortifications are placed where the road meets the river or the river is less wide ${ }^{77}$.

Rivers played an important role in how the Roman army was placed, being considered rather as means of communication/supply than natural frontiers. They were suited for cheaply and quickly transporting large quantity of goods and large number of men. This helps us understand how legionary fortifications were placed in provinces with artificial barriers: Britannia, Upper Germany, Dacia. Here the legions spend a lot of time inside the province, as far as $150 \mathrm{~km}$ away from the border, not because of in-depth defence (it was not needed) but because they had access to rivers for supplies ${ }^{78}$.

As far as artificial barriers are concerned, it is more and more obvious the played no defensive role. Hadrian's Wall served to control traffic and commerce. Upper German-

\footnotetext{
72 Dio 68.13.5-6; RANKOV 2005, 177-8.

73 Tacitus, Hist. 4.26.

74 Ovidius, Trist. 3.10.27; Plinius, Pan. 12.3.

75 Tacitus, Ann. 2.8

76 RANKOV 2005, 178-81.

77 SOMMER 2009, 111-2.

78 SOMMER 2009, 212.
}

Raetian Limes served to stop small invasions, supervise the area and signal danger. In the first example we see traffic and roads going outside the border while this is not true for the second (because it was in itself a road between the Rhine and Danube $)^{79}$. The purpose of artificial barriers is to control traffic along the line of the frontier, both incoming and outgoing. This is what the buildings and communication lines unearthed tell us. How they functioned together is a completely different matter ${ }^{80}$.

Artificial barriers, especially those from continental Europe, share many traits with the river barriers: firstly they start off as a fortified road; secondly they become individual defence lines. They were not impregnable but their role was to slow down any small invasion and to signal to the legionary fortifications - the latter would send troops to intervene ${ }^{81}$. Still, in very rough areas such as the limes porolissensis the army would not take action against enemies situated on a hilltop but rather waited for the invaders.

Although attempts at expansion existed after Augustus - Claudius, Nero, Vespasian, Domitian, Trajan, Marcus Aurelius, Septimius Severus - we can notice a change in the military strategy of the Empire from the middle $2^{\text {nd }}$ century onwards: defence along a militarized, defined line, enclosing the civilized world in a ring and preventing pointless expansion. ${ }^{82}$ Still, Roman writers contemporary with Hadrian do not rule out the idea of an Empire without an end. Following Augustus and until Trajan, with the exception of Britannia, no significant expansion was achieved. Client kingdoms were anyway considered part of the Empire and the transformation of some of them in provinces involved only an administrative change. The policy of these client states goes even further, with diplomacy having the first role. The Flavian dynasty continues the policies previously conducted by the Julio-Claudian dynasty. Agri decumates was occupied in order to eliminate a dangerous area between the Rhine and Danube and the line between the fortifications and the Taunus Mountains is not a limes but rather a guarded road. It is now that the military forces are concentrated along the rivers, the Rhine and the Danube, but the borders - which are still relative - are not fortified. It is only during Hadrian's rule that we notice the Empire adopting a new defensive policy. However some areas are fortified even during Trajan's time - the Odenwald limes, the line that will become Hadrian's Wall. In Africa, the line of fortifications known as the fossatum Africae is believed to have been built by Hadrian but it seems Trajan built some clausurae south of this line (again we notice Hadrian's withdrawal). Still, the Romans do not consider they cannot surpass these limits: Dacia, the project involving the creation of new provinces in Bohemia and Slovakia, Septimius Severus' expansion into Scotland etc. ${ }^{83}$

Dacia and the Dacian limes are an expression of the Roman strategy at the lower Danube. Practically the province divides the Sarmatian lands then controls the two sides through diplomacy. After he removes the only danger

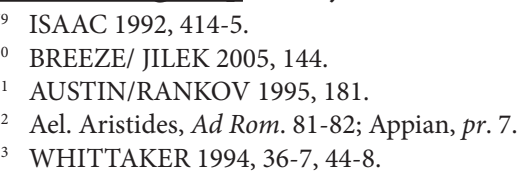


of a centralized state in the area, Trajan creates a strong climate of security needed for the durable development of lower Danube and Dobruja, this starting from this point forward. The Dacian limes is a succession of defensive points, without a continuous defensive barrier, because its role was to block access in Transylvania along the trans-Carpathian ways, which are rather few and inaccessible. Initially Trajan brings a much larger territory in the Empire but following the Sarmatian attack of A.D. 116-119, Hadrian decides the withdrawal around Transylvania and the Drobeta-ApulumPorolissum imperial road. It is only in the $3^{\text {rd }}$ century, when control of the Sarmatians is no longer exercised, that this limes becomes vulnerable and must be abandoned ${ }^{84}$.

In the East we can clearly see that the border in fact is but a supervised and controlled road. Actually the Romans were more preoccupied with defending their own ways of communication rather than forbidding foreigners access to them ${ }^{85}$.

Here the situation is basically opposite from the west side of the Empire: the reason for expansion is wealth, contact is established with organized, centralized, Hellenistic states, the most important one being Parthia. Up to a certain degree the Euphrates served as a border compromise between Rome and Parthia but the border stretches from the Caucasus Mountains and the Black Sea until the Sinai desert and the Red Sea, going through different landscapes. The eastern frontier becomes more and more difficult to defend: from the 3-4 legions placed there by Pompey, the number increases to 8 in the $2^{\text {nd }}$ century and even 10 under Septimius Severus. Expansion stops somewhat in this area, with the exception of some client kingdoms being incorporated but such kingdoms were already considered an integral part of the Empire. Augustus prefers Armenia as a client state but this gift made by the Romans can be revoked at any moment. The situation of Palmyra is unclear, probably a sort of control without actual ruling it ${ }^{86}$.

The Flavians are those who start establishing an eastern frontier. They resettle the legions along the Euphrates, two in Cappadocia, at least two in Syria but this proves that the river was not an effective border but a line of communication, the legions being always placed along a fortified line inside the province. In fact we encounter remains and traces of the Flavian armies more often beyond the Euphrates than on the Roman controlled shore. Trajan chose to extend this frontier but only to fortify a line behind it - the Euphrates - while Hadrian had only defensive goals. His withdrawal from the provinces conquered by his adoptive father meant going back to a concept of control without rule. This area will be disputed by both Marcus Aurelius and Septimius Severus, indicating the relativity of the notion of frontier in the Roman Orient. In northern Mesopotamia only the mode of administration is changed, from controlled to occupied territory but the cities are rather free so no form of border can be established. Going further south, in Arabia, the Romans only fortified the former royal road from Bosra

\footnotetext{
84 LUTTWAK 1976, 97, 100-1, 104

85 ISAAC 1992, 416.

86 WHITTAKER 1994, 49-51, 53-4
}

to the Red Sea - via nova Traiana, in order to escort caravans and supervise the nomads ${ }^{87}$.

In the East the defence was more varied and adapted to the local conditions. The access points from Armenia, few and narrow, are filled with troops (auxiliaries from the shores of the Black Sea, legions in the mountain) and crossing points across the Euphrates were again controlled by the legions. More to the south, where there was desert, fortifying caravan roads was essential as this is the only invasion path and internal security in the troubled area of Palestine was also very important ${ }^{88}$. In Egypt the situation is similar. Alexandria was controlled by one legion which also had access to the mouths of the Nile and control over the rest of the valley was well established by the auxiliaries, just as the roads between the Nile and the Red Sea that pass through the mining districts.

The eastern frontier was thus a fortified communication line from where the Romans exercised control or launched offensives (in the conflicts with Parthia it is almost always the Romans who are the aggressors) thus it has an offensive character rather than the defensive one of the western border ${ }^{89}$.

The Marcomannic Wars were the first major breach of the Roman limes and the Romans chose to strengthen and maintain the borderline instead of opting for an in-depth defence. Septimius Severus did the same and only after the many crises of the $3^{\text {rd }}$ century do the Romans completely switched to fortifying on individual positions. When the Eastern front became active again in A.D. 162 many troops were moved there from the Danube. The partial success and the disaster that followed allowed for the greatest barbarian invasion in the Empire, with the Marcomanni reaching Aquileia. The barbarian conspiracy took the Romans by surprise but, as they chose to enlist two new legions, the situation was resolved in eight years. The following Roman invasion, which was planned and was only natural, no longer took place ${ }^{90}$.

The concept of the Grand Strategy of the Roman Empire has however some weak spots, speculated upon by some authors. Decisions are taken on a personal basis, mostly by the emperor, who may or may not have a strategic sense but not a strategy - a concept unknown to the ancients. Still, there was a point from where Roman jurisdiction was applied (including client states), but the Romans did not have the modern concept of border. Demarcation lines established by them in different areas separate and divide but are bureaucratic and administrative limits. A frontier area unites and integrated cultural diversity - before the Romans reached the Rhine this was not a border between cultures. To conclude, there were no borders in the modern meaning of the word, namely contact areas between Rome and the enemy while the system of client states was not abandoned by the Flavian and the Antonine dynasty but preserved during the whole period of the Empire ${ }^{91}$.

\footnotetext{
WHITTAKER 1994, 55-8.

AUSTIN/RANKOV 1995, 182-3.

WHITTAKER 1994, 59.

LUTTWAK 1976, 130-2, 145-7.

ISAAC 1992, 416; WHITTAKER 1994, 68-74, 84.
} 


\section{CONCLUSIONS}

Rome integrated the barbarians inside its borders but did not manage to create a social atmosphere that could satisfy the entire world. Also by abandoning the mission of expansion, it planted the seeds of its own destruction at the hands of those it did not conquer ${ }^{92}$.

Territory was important for Romans only as far as income is concerned. Natural barriers were supply ways and the artificial one served to regulate traffic. Fortifications did not also play a defensive role and this was not mentioned or proved in Antiquity ${ }^{93}$.

Most of the inhabitants around the border areas, nonRomans, had regular contacts with barbarians living beyond the frontier - thus they lived in an open space ${ }^{94}$. The most important factor of unity along the European border is the army. It maintains a permanent and mutually advantageous relation with the civilian population: it is not separated from it but tries to integrate within it - practically they build the Roman frontier world ${ }^{95}$. Theories about populations living around the limes lead us to the conclusion that decisions were taken especially at the economic levels, the occupied areas being developed before the arrival of the Romans; the southern half of Britannia, the agri decumates but not the northern area of the lower Rhine, Bohemia, Slovakia, but not Bavaria etc. In Africa and the East - regions with a climate and ecosystem different from Europe, the frontier appeared exactly where the line separated the fertile land and the desert (the Fertile Crescent). Thus the rational behind stopping the expansion in these areas are economic. The ability of such an area for surplus, for feeding the army and for the development of society was this most important factor in such decisions ${ }^{96}$.

The conclusion was best put forward by Drummond and Nelson: 'the Roman frontier is practically an area permanently active - an opportunity' ${ }^{97}$.

\section{ACKNOWLEDGEMENTS}

This work was possible due to the financial support of the Sectorial Operational Program for Human Resources Development 2007-2013, co-financed by the European Social Fund, under the project number POSDRU/159/1.5/S/140863 with the title "Competitive European researchers in the fields of socio-economics and humanities. Multiregional research network (CCPE)".

\section{REFERENCE LIST}

AUSTIN/RANKOV 1995

Austin, N.J.E., Rankov, N.B., Exploratio: military and political intelligence in the Roman world from the Second Punic War to the battle of Adrianople (London - New York: Routledge).

\section{BREEZE/JILEK 2005}

Breeze, D.J., Jilek, S., Strategy, Tactics, Operation. How did DOBSON 1986

Frontiers Actually Work, Limes XIX Pecs, 141-6.

Dobson, B., The Function of Hadrian's Wall, Archaeologia Aeliana 5/14, 1-30.

\footnotetext{
92 MANN 1979, 183.

93 ISAAC 1992, 417-8; WHITTAKER 1994, 91.

94 ELTON 1996, 38: Ammianus 21.4.3, 29.6.5, 31.5.5.

95 DRUMMOND/NELSON 1994, 33.

96 WHITTAKER 1994, 85-7, 89-90, 92-3, 95-7.

97 DRUMMOND/NELSON 1994, 34.
}

\section{DRUMMOND/NELSON 1994}

Drummond, S.K., Nelson, L.H., The western frontiers of imperial Rome (London - New York: Routledge).

\section{DYSON 1985}

Dyson, S.L., The Creation of the Roman Frontier (Princeton: Princeton University Press).

\section{ELTON 1996}

Elton, H., Frontiers of the Roman Empire (London - New York: Routledge).

FINK 1971

Fink, P.O., Roman Military Records on Papyrus (Cleveland: Case Western Reserve University Press).

GUDEA 1979

Gudea, N., The Defensive System of Roman Dacia, Britannia 10, 63-87.

\section{GUDEA 1997}

Gudea, N., Der Dakische Limes. Materialen zu seiner Geschichte, JRGZM 44, 1-113.

\section{HODGSON 2005}

Hodgson, N., Gates and passage across the frontiers: the use of openings through the barriers of Britain, Germany and Raetia, Limes XIX Pecs, 183-8.

\section{ISAAC 1992}

Isaac, B., The Limits of Empire: the Roman army in the East (Oxford: Clarendon Press).

\section{KENNEDY 1996}

Kennedy, D.L., The Roman Army in the East, JRA Supplemental Series 18.

\section{LUTTWAK 1976}

Luttwak, E., The grand strategy of the Roman Empire from the first century $A D$ to the third (Baltimore - London: Johns Hopkins University Press).

\section{MANN 1974}

Mann, J.C., The Frontiers of the Principate, ANRW II.1, 508-33.

\section{MANN 1979}

Mann, J.C., Power, Force and the Frontiers of the Empire, JRS 69, 175-83.

\section{MATTERN 1999}

Mattern, S.P., Rome and the Enemy. Imperial Strategy in the Principate (Berkeley - Los Angeles - London: University of California Press).

\section{MAXFIELD 2005}

Maxfield, V., Organization of a desert limes: the case of Egypt, Limes XIX Pecs, 201-12.

\section{RANKOV 2005}

Rankov, B., Do rivers make good frontiers?, Limes XIX Pecs, 175-81.

\section{SOMMER 2009}

Sommer, C.S., Why there? The positioning of forts along the riverine frontiers of the Roman Empire, The Army and Frontiers of Rome. Papers Offered to David J. Breeze on the Occasion of his sixty-fifth Birthday and his Retirement from Historic Scotland (ed. W.S. Hanson), JRA Supplemental Series 74, 103-14.

\section{THORNE 2007}

Thorne, J., Battle, Tactics and the Emergence of the limites in the West, A Companion to the Roman Army (ed. P. Erdkamp), 218-34.

WHEELER 2007

Wheeler, E.L., The Army and the limes in the East, A Companion to the Roman Army (ed. P. Erdkamp), 235-66.

\section{WHITTAKER 1994}

Whittaker, C.R., Frontiers of the Roman Empire. A Social and Economic Study (Baltimore: Johns Hopkins University Press). 


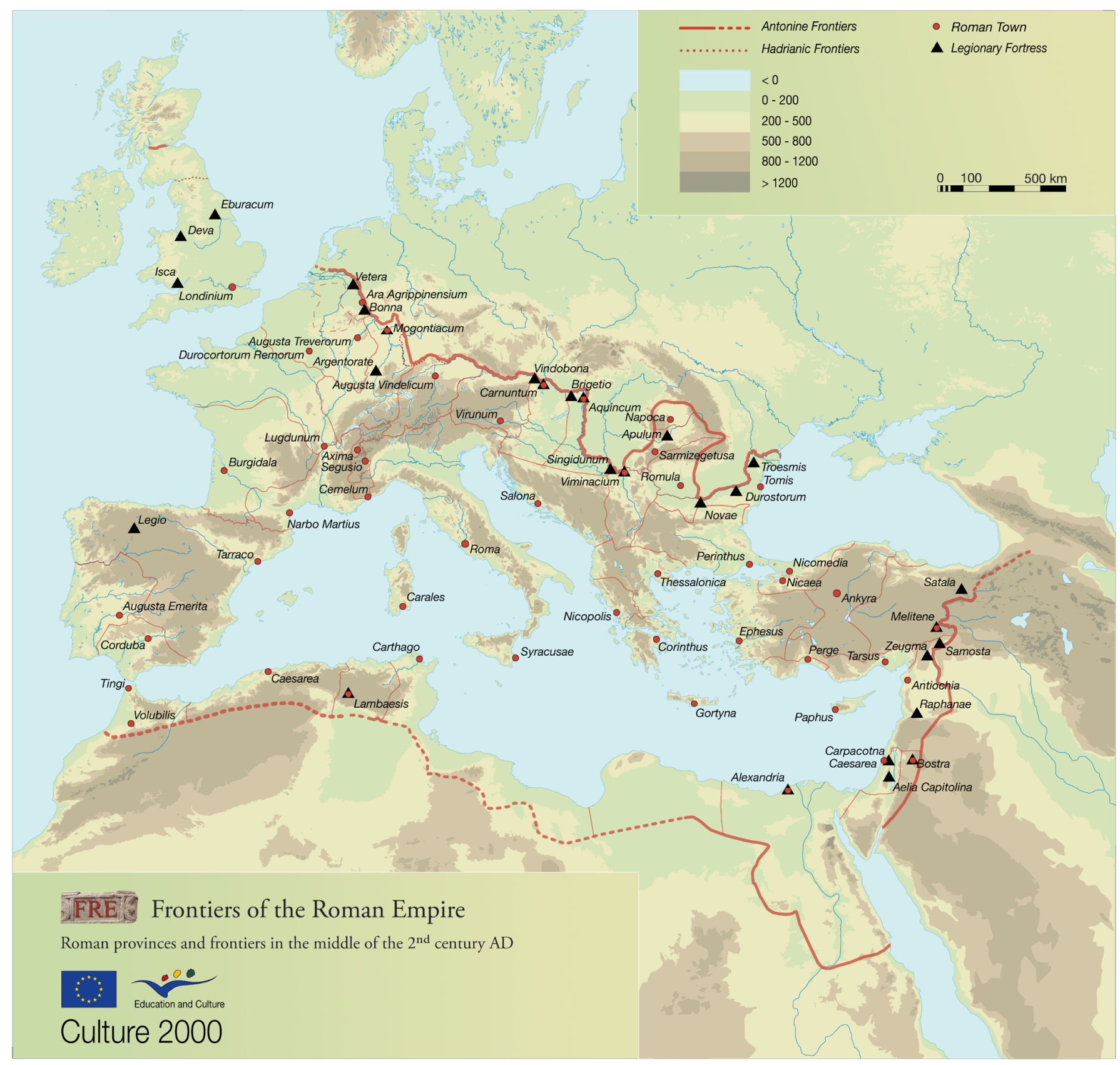

Frontiers of the Roman Empire - mid. 2nd century A.D. 


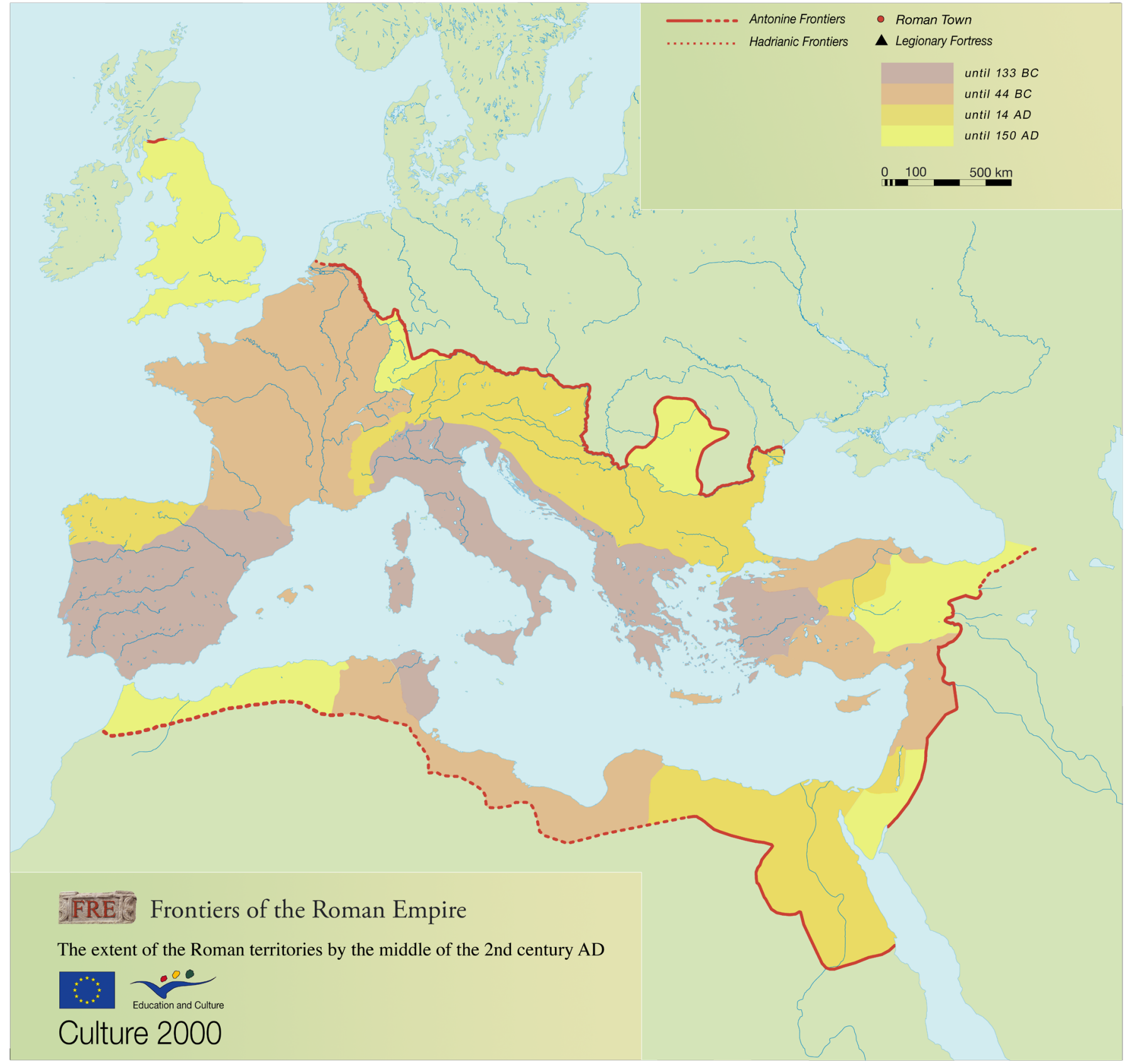

Chronological map of the Roman Empire 